\title{
Barriers to Islamic Banking Growth- Bank Employees’ Perspective from Pakistan
}

\author{
Adnan Bashir \\ Lecturer, Faculty of Management \& Administrative Sciences \\ University of Gujrat, Pakistan \\ E-mail: adnan.bashir@uog.edu.pk \\ Mirza Rizwan Sajid \\ Lecturer, Faculty of Statistics University of Gujrat, Pakistan \\ E-mail: mirza.rizwan@uog.edu.pk
}

Samra Iqbal

Mphil Scholar, Department of Economics University of Gujrat, Pakistan

E-mail: samrabashir@yahoo.com

Received: September 1, 2011

Accepted: November 20, 2011 Published: December 1, 2011

doi:10.5296/ajfa.v3i1.918

URL: http://dx.doi.org/10.5296/ajfa.v3i1.918

\begin{abstract}
The concept of Islamic banking (IB) in Pakistan traces its roots back to late 70s. Since its inception it has had its fair share of growth. The IB industry, despite its growth during the last few years, has not fully nurtured and its share in banking industry is moderate $6.4 \%$. This study explores the view point of bank employees of Gujranwala Division Pakistan regarding this statistics. By using a sample of 126 respondents, comprising Islamic bank employees (IBE) and conventional bank employees (CBE) to investigate the factors responsible for low market share of Islamic banking in banking industry. Our findings indicate that according to over all sample small network of branches, inadequate info about Islamic banking services, ignorance to teachings of Islam, trust deficiency towards Interest free banking and location of banks as the main reason for mere rise of Islamic banking. The factors change if we divide our sample in subsamples of IBE and CBE. Although considerable work in this area has been done in world and Pakistan is no exception to this however, the focus of majority of research
\end{abstract}




\section{Macrothink}

Asian Journal of Finance \& Accounting ISSN 1946-052X

is on the customers view point. This paper explores the roots of modest share of IB from bank employees' angle.

Keywords: Bank Employees, Conventional banking, Employees, Financial system, Islamic banking. 


\section{Introduction}

The concept of Islamic financial system (IFS) is as old as the religion Islam itself. According to Moin (2008) it dates back to the life of the Holy Prophet Muhammad (PBUH), about fifteen centuries ago when He acted as an agent for His wife business dealings. IFS has evolved over the years \& the phenomenon which started off as a mere means to fulfill religious obligation has now turned into a more structured \& organized way of banking in the current challenging \& difficult economic climate. In the last quarter of 20th century, Islamic finance industry has made significant progress globally. Moreover, during the last decade or so the IFS have registered a tremendous increase of about 20 percent per annum. Due to this it has become one of the fastest growing sectors of the overall financial system.

The breeding seeds of this revolutionary concept of IB were sown in late 1940's \& by 1960's \& 1970's IB started taking a meaningful shape. According to Sikand (1997) traces of first Islamic bank are found in the area of Mit Ghamr in Egypt in 1963 when first interest free Islamic bank was formed \& from onwards it has never looked back. In the years to come IB took more momentum \& with the increasing influence of Middle Eastern countries on the world economy, due to their oil reserves more and more traditional western banks started establishing their own subsidiaries or partnerships practicing interest free banking in Muslim countries. According to Warde (2010) the decade of 1970 saw the emergence of so many Islamic banks namely Dubai Islamic Bank (1975), Kuwait Finance House (1977), Faisal Islamic Bank of Egypt (1977), Islamic Bank of Sudan (1977), Jordan Islamic Bank of Finance \& Investment (1978), Bahrain Islamic Bank (1978) and Islamic International Bank for Investment.

In Pakistan during late 70's serious efforts were put into action to Islamize the economy and that laid the foundation for modern IB. However it took some time to flourish IB. According to Awan (2009) the growth of IB in Pakistan accelerated since 2002. This was the time when State Bank of Pakistan changed its approach to introduction of IB as a change management issue. According to State Bank of Pakistan (2008) the first full- fledged commercial Islamic Bank license was issued in 2002[1]. Currently there are 6 full- fledged Islamic banks and 13 conventional banks offering Islamic products. Although Islamization of economy was started in late 70's, still IB phenomenon has not fully borne fruit and that is reflected in its modest market share of $6.4 \%$. This figure looks even more surprising, that about $98 \%$ people are Muslims and being a conservative society religious beliefs hold a central importance and place in the overall thinking process. Although a lot of work has been done in this area from customer's point of view, but studies focusing on employees are very few. According to Quagraine (2010) employees are the source of energy for the organization. Their non involvement in decision making can alter the performance of the organization. This study is an effort to bridge the gap of lack of literature in this area. Moreover the recommendations of this study can be used by the policy makers to devise a framework for growth of IB.

\section{Literature Review}

In order to understand the real causes of lack of growth of IB in Pakistan we need to discuss in detail what really matters according to employees. Studies focusing on employees' point of 
view are very few; hence we will concentrate on what influences customers' choice or decision of doing business with any particular bank. Different researchers have listed numerous selection criteria \& they vary across the globe.

According to Erol and El-Bdour (1989) availability of fast and efficient services, image of bank and its reputation and confidentiality were the most important factors. They conducted a study on Jordanian customers. They were of the view that religion was not the most important reason to select financial institution.

Sudin et al. (1994) observed the behavior of Malaysian customers. They were of the opinion that provision of fast and efficient services, speed of the transaction and reputation and image of the bank were the main factors that customers consider important while choosing the financial institution

Hegazy (1995) carried out a research on the attitude of Egyptian customers. His respondents were Islamic bank customers. He reached at the result that efficiency and speed of delivering banking services were the most crucial elements in the selection of bank.

Gerrard and Cunningham (1997) performed study on the Singapore customer. They wanted to explore the awareness of customers towards the Islamic banking products. Their findings highlighted the need of strong advertising campaign to overcome the lack of awareness of the customer regarding the IB.

A study was conducted by Naser et. al (1999) on Jordan Banks clients. They highlighted the opening time of banks as not helpful.

According to Rammal and Zurbruegg (2006) strong image and availability of services like ATM and phone banking were the important contributors in customer selection of Islamic Banking products. They explored the awareness of Australian Muslims towards Islamic banking. They pointed out that people were interested in IB products; however unawareness to these products was the biggest hurdle in this regard.

Dusuki and Abdullah (2006) conducted a research on why do Malaysian customers patronize Islamic banks and they found out that the provision of offering Islamic banking services should not be taken as far granted success. Other factors like cost \& benefits of products offered, service quality, convenience and size of the bank were equally important if not more important which influence customers' choice.

Haque et. al (2009) stressed upon the importance of availability of good quality services to influence customers' perception about Islamic bank. In addition to this social culture and religion was also playing its role in this regard. They performed their research on Malaysian customer choices.

Al-Ajmi et. al (2009) after studied the attitude of Bahrain clients and identified quality of customer service, friendly staff, qualified personnel, bank brand name, convenience in terms of parking space and interior design of bank as the main factor for selection of bank.

Rashid and Hassan (2009) looked at the responses of Bangladesh customers'. They arrived at 
the conclusion that fast and efficient services, speed of the transaction were the most preferred factors in choosing an Islamic bank. They negated the religion as basic criteria for selection of bank.

Abduh and Omar (2010) identified the compliancy to shariah laws, Knowledge of Ulama Council of Indonesia (MUI) fatwa towards interest, perceptions towards security of capital and advertisement of Islamic banks as the most important variables for banks. They explored the obstacles to Indonesian customers.

Khattak \& Rehman (2010) analyzed the customers' contentment and their knowledge about Islamic banking products in Pakistan. Their findings suggested that Islamic banking products were not well known to majority of customers. In their view, branch location was playing a vital role in this regard. Moreover they argued that Islamic banks must offer more efficient products to their customers.

Mansour et. al (2010) after analyzing the UK respondents' behavior pin pointed the cost as the main reason for choosing a bank.

\section{Research Methodology}

\subsection{Data}

A well structured questionnaire was used to collect the data from the respondents. This instrument of data collection consisted of two sections: IST section aimed to obtain socio-demographic information about the respondents and the 2nd part solicited information about the 9 possible obstacles faced by employees of Islamic \& conventional banks. These motives were drawn mainly from earlier studies cited above. In the 2nd part five point Likert Scale was used to obtain answers from respondents. The population of the study consisted of the employees of Islamic and conventional banks. They were randomly selected from Gujranwala division. The researcher distributed the questionnaire among a sample size of around 160 people. Out of those distributed questionnaires, 126 were fully answered while the remaining 34 were either partially answered or not answered at all. Researcher went to extra length to make sure that selected sample had diversification in demographic characteristics. Pre testing was also done to check the validity of questionnaire.

\subsection{Methodology}

Stratified Random Sampling was used to select the sample. It was considered that conventional and Islamic bank employees might have different opinions about the barriers of IB growth. So population of bank employees was divided into two groups: Conventional bank employees (CBE) and Islamic bank employees (CBE). Proportion allocation method was used to select the sample from these two said groups.

Chi-Square test of Homogeneity was used to see the difference among more than two categories of responses. For barriers to IB growth 5-point likert scales converted into 3-point for data analysis. Strongly agree and agree considered to be one category as agree and strongly disagree and disagree as disagree. This test shows which category proportion is different from other? So on the basis of this test we can say which assumed factor is 
confirmed in this research. It is important to note that we should not only focus on the p-value for the confirmation of factors. We also have to see the proportions of category which has significantly high frequency. It shows that result move towards that direction e.g. high frequency of agree with p-value < level of significance shows that factor is significant barrier for IB end vice versa.

\section{Empirical Results}

Out of 126 respondents 101 were male which constituted $80.2 \%$ of sample while remaining $19.8 \%$ were female respondents. With respect to age of participants, age group of 25 to 35 was the largest with a figure of $39.7 \%$. Participants of 55 years or elder were in the least quantity. According to the education of the respondents, people with graduation had lion's share of around 49\%. Around $39.7 \%$ people had attained master's qualification. These statistics show that majority of our sample was highly qualified. If we turn our attention to marital status of correspondents here married people had a figure of $63.5 \%$ as compared to $37.5 \%$ of single.

The researcher found out that $29 \%$ respondents were earning 25,000 or less, $49.2 \%$ between 25,000 to 50,000 . While $16.7 \%$ were earning between 50,000 and 100,000 , while 6 participants were earning above 100,000. The above percentage shows that majority of the respondents were earning 50,000 or less per month.

With respect to type of banking, majority of bankers in our population were employees of conventional banks. Their percentages stood at $69.8 \%$ while employees of Islamic banks had less proportion with $31.2 \%$. The researcher observed that 5-10 years experience category had $25.4 \%$ while less than 3 years experience people were $24.6 \%$. In this category least percentage of 18.3 was of respondents with 15 or more year's experience. Table 1 presents descriptive statistics of the respondents. 
Table 1. Demographic characteristics of the sample

\begin{tabular}{|c|c|c|c|}
\hline Demographic & Categories & Frequency & $\%$ \\
\hline \multirow[t]{5}{*}{ Age } & Under 25 & 23 & 18.3 \\
\hline & $25-35$ & 50 & 39.7 \\
\hline & $35-45$ & 29 & 23.0 \\
\hline & $45-55$ & 14 & 11.1 \\
\hline & above 55 & 10 & 7.9 \\
\hline \multirow[t]{2}{*}{ Sex } & Male & 101 & 80.2 \\
\hline & Female & 25 & 19.8 \\
\hline \multirow[t]{5}{*}{ Education } & Matric & 7 & 5.6 \\
\hline & Intermediate & 6 & 4.8 \\
\hline & Graduation & 61 & 48.4 \\
\hline & Master & 50 & 39.7 \\
\hline & Other & 2 & 1.6 \\
\hline \multirow[t]{2}{*}{ Marital Status } & Single & 46 & 36.5 \\
\hline & Married & 80 & 63.5 \\
\hline \multirow[t]{5}{*}{ Monthly Income } & $0-10000$ & 1 & .8 \\
\hline & $10000-25000$ & 36 & 28.6 \\
\hline & $25000-50000$ & 62 & 49.2 \\
\hline & 50000-100000 & 21 & 16.7 \\
\hline & above 100000 & 6 & 4.8 \\
\hline \multirow[t]{2}{*}{ Banking Type } & Islamic & 38 & 30.2 \\
\hline & Conventional & 88 & 69.8 \\
\hline \multirow[t]{5}{*}{ Years of Experience } & Less than 3 & 31 & 24.6 \\
\hline & $3-5$ & 24 & 19.0 \\
\hline & $5-10$ & 32 & 25.4 \\
\hline & $10-15$ & 16 & 12.7 \\
\hline & above 15 & 23 & 18.3 \\
\hline
\end{tabular}

\subsection{Barriers to Overall Sample}

Table II shows the opinion of IBE and CBE as a whole regarding the lack of the growth of IB. In this research 77 out of 126 employees of banks (conventional and Islamic both) are of the view that ignorance to teachings of Islam with respect to financial transactions is a major factor for low market share of IB. The test of Homogeneity of proportions resulted that this proportion is significant at 0.05 level of significance. So ignorance to teachings of Islam regarding financial matters is an important factor for growth of IB system. This shows that religion is an important consideration for low market share of IB for the respondents of this 
study. This is in-align with the study of Haque et. al (2009) and Mansour et. al (2010). These studies considered religion as important reason.

When we turn our attention to trust deficiency towards Interest free banking, facts and figures show that most of bank employees think that people do not trust IB regarding interest free setup. The present factor is also confirmed through test of Homogeneity at 0.05 level of significance with p-value .of 000 . This could be explained by the fact that Pakistan is an Islamic country in which majority of people has perception about banking system as interest based set up, which is not allowed in Islam. So people think that any type of banking cannot be free of interest. Here findings of our research are consistent with that of Abduh and Omar (2003).

Although IB is more than 30 years old, however people are not aware of its products and services. According to our study Inadequate information about Islamic banking products and services is important factor for lack of growth of IB. Test of Homogeneity at 0.05 level of significance also verifies this. In our study 84 out of 126 respondents said that it is a significant factor for low market share of IB. This view was shared by the work of Gerrard and Cunningham (1997) and Rammal and Zurbruegg (2006).

Experienced and skilled human resource is required for effective and efficient system. Shortage of experienced and qualified staff is also significant hindrance for growth of IB according to our sample. According to this study 67 out of 136 agree with this. p- value of 0.000 is also significant at 0.05 level of significance. Here our findings were in line with that of Al-Ajmi et. al (2009).

Literature review showed that Non availability of good quality customer services is also playing its part in low market share of IB. But according to our findings it is not significant factor, because majority of bank employees show their disagreement about it. It means that in Pakistan IB are providing good customer services. Results disagreeing with inadequate information about Islamic banking service are significant.

Low effectiveness of services is not a hurdle for IB progress. According to results of our research, number of respondents agreeing and disagreeing to this is almost equal. The results is not significant due to proportional difference between agree and disagree but due to huge difference from neutral group.

Previous researches also identified high cost of IB products as main reason for its low market share. But this research also rejects this notion. The reason for this is the frequency of people for and against this is almost equal. Moreover p-value is also insignificant at 0.05 level of significance.

Employees of banking system were of the view that small network of branches and their locations are very important hurdle in the progress of IB system. Both these factors are significant at.05 level of significance. Here our results also support the view point of Khattak \& Rehman (2010).

Thus according to the whole group significant factors for low share of IB are 
1) Small network of branches

2) Inadequate info about Islamic banking services

3) Ignorance To financial Teachings of Islam

4) Trust deficiency towards Interest free banking

5) Location of banks

6) Shortage of experienced and qualified staff

Table 2. Test Result of Overall Sample

\begin{tabular}{|c|c|c|c|c|c|}
\hline Factors & & $\begin{array}{l}\text { Observed } \\
\mathrm{N}\end{array}$ & $\begin{array}{l}\text { Expected } \\
\mathrm{N}\end{array}$ & Residual & $\begin{array}{l}\text { Chi Square Test Value } \\
\text { with Significance }\end{array}$ \\
\hline \multirow{3}{*}{$\begin{array}{l}\text { Ignorance To financial } \\
\text { Teachings of Islam }\end{array}$} & Disagree & 32 & 42.0 & -10.0 & \multirow{3}{*}{$\begin{array}{l}46.429 \\
.000^{*}\end{array}$} \\
\hline & Not sure & 17 & 42.0 & -25.0 & \\
\hline & Agree & 77 & 42.0 & 35.0 & \\
\hline \multirow{3}{*}{$\begin{array}{l}\text { Trust deficiency towards } \\
\text { Interest free banking }\end{array}$} & \begin{tabular}{|l|} 
Disagree \\
\end{tabular} & 32 & 42.0 & -10.0 & \multirow{3}{*}{$\begin{array}{l}46.429 \\
.000^{*}\end{array}$} \\
\hline & Not sure & 17 & 42.0 & -25.0 & \\
\hline & Agree & 77 & 42.0 & 35.0 & \\
\hline \multirow{3}{*}{$\begin{array}{l}\text { Inadequate info about } \\
\text { Islamic banking services }\end{array}$} & Disagree & 27 & 42.0 & -15.0 & \multirow{3}{*}{$\begin{array}{l}64.714 \\
.000^{*}\end{array}$} \\
\hline & Not sure & 15 & 42.0 & -27.0 & \\
\hline & Agree & 84 & 42.0 & 42.0 & \\
\hline \multirow{3}{*}{$\begin{array}{l}\text { Shortage of experienced } \\
\text { and qualified staff }\end{array}$} & Disagree & 44 & 42.0 & 2.0 & \multirow{3}{*}{$\begin{array}{l}32.333 \\
.000^{*}\end{array}$} \\
\hline & Not sure & 15 & 42.0 & -27.0 & \\
\hline & Agree & 67 & 42.0 & 25.0 & \\
\hline \multirow{3}{*}{$\begin{array}{l}\text { Non availability of good } \\
\text { quality customer services }\end{array}$} & Disagree & 61 & 42.0 & 19.0 & \multirow{3}{*}{$\begin{array}{l}25.857 \\
.000^{*}\end{array}$} \\
\hline & Not sure & 16 & 42.0 & -26.0 & \\
\hline & Agree & 49 & 42.0 & 7.0 & \\
\hline \multirow{3}{*}{$\begin{array}{l}\text { Low effectiveness of } \\
\text { services }\end{array}$} & Disagree & 54 & 42.0 & 12.0 & \multirow{3}{*}{$\begin{array}{l}10.905 \\
.004^{*}\end{array}$} \\
\hline & Not sure & 25 & 42.0 & -17.0 & \\
\hline & Agree & 47 & 42.0 & 5.0 & \\
\hline \multirow{3}{*}{$\begin{array}{l}\text { High cost of banking } \\
\text { products and services }\end{array}$} & Disagree & 47 & 42.0 & 5.0 & \multirow{3}{*}{$\begin{array}{l}2.905 \\
.234\end{array}$} \\
\hline & Not sure & 33 & 42.0 & -9.0 & \\
\hline & Agree & 46 & 42.0 & 4.0 & \\
\hline \multirow{3}{*}{ Small network of branches } & Disagree & 21 & 42.0 & -21.0 & \multirow{3}{*}{$\begin{array}{l}86.333 \\
.000 *\end{array}$} \\
\hline & Not sure & 14 & 42.0 & -28.0 & \\
\hline & Agree & 91 & 42.0 & 49.0 & \\
\hline \multirow{3}{*}{ Location of banks } & Disagree & 38 & 42.0 & -4.0 & \multirow{3}{*}{$\begin{array}{l}19.619 \\
.000^{*}\end{array}$} \\
\hline & Not sure & 24 & 42.0 & -18.0 & \\
\hline & Agree & 64 & 42.0 & 22.0 & \\
\hline
\end{tabular}

* significant at .05 level of significance 
4.2 Factors for Subsample:

It was decided to divide the sample into two subsamples i.e. conventional and Islamic and compare the factors responsible for growth of IB system. Our sample consisted of 38 \& 88 respondents respectively. Table III and Table IV highlight these factors.

With respect to 1st factor of ignorance to teachings of Islam, total sample agreed that ignorance to teachings of Islam is a big barrier for IB growth. Both of our subsamples i.e. Islamic and conventional bank employees in table III and IV also come to same conclusion. However according to IBE this is more of concern as compared to CBE due to no. of respondents in favor of this are in much higher proportion in Islamic than conventional.

Next comes the factor of trust deficiency towards interest free banking system. The overall sample confirms this as significant hurdle in the expansion of this IB. Results of both subsamples also think that this is a significant factor. But like previous factor this is much more important to IBE as compared to CBE. It can be observed that IBE are giving it more weight than CBE. In this case, 30 out of 38 of IBE are in favor of this factor, however in CBE only 47 out of 88 agree with this. So it is an important factor for both but IBS employees are more strongly agree to this than CBS employees.

IBE also give assign more weight to the inadequate information about Islamic banking products and services as compared to CBE counterparts. This is similar to previous factor situation.

In the overall sample, we can see that shortage of experienced and qualified staff is a significant factor. However in case of IBE, is not significant however CBE consider this to be an important factor. It can be said that IBE are biased because being the respondents of this study; they may not consider themselves as unqualified and inexperienced.

In the next case non-availability of good and quality customer services, both types of employees show consensus that this is not a barrier to IBS. It can be observed that in both situations, disagree proportion is high. These results are significant at 0.05 level. 


\section{Macrothink}

Asian Journal of Finance \& Accounting

ISSN 1946-052X

2011, Vol. 3, No. 1: E4

Table 3. Test Result of Islamic Banking

\begin{tabular}{|c|c|c|c|c|c|}
\hline Factors & & $\begin{array}{l}\text { Observed } \\
\mathrm{N}\end{array}$ & $\begin{array}{l}\text { Expected } \\
\mathrm{N}\end{array}$ & Residual & $\begin{array}{l}\text { Chi Square Test value } \\
\text { with Significance }\end{array}$ \\
\hline \multirow{3}{*}{$\begin{array}{l}\text { Ignorance To financial } \\
\text { Teachings of Islam }\end{array}$} & Disagree & 2 & 12.7 & -10.7 & \multirow{3}{*}{$\begin{array}{l}40.158 \\
.000 *\end{array}$} \\
\hline & Not sure & 5 & 12.7 & -7.7 & \\
\hline & Agree & 31 & 12.7 & 18.3 & \\
\hline \multirow{3}{*}{$\begin{array}{l}\text { Trust deficiency } \\
\text { towards Interest free } \\
\text { banking }\end{array}$} & Disagree & 7 & 12.7 & -5.7 & \multirow{3}{*}{$\begin{array}{l}37.000 \\
.000 *\end{array}$} \\
\hline & Not sure & 1 & 12.7 & -11.7 & \\
\hline & Agree & 30 & 12.7 & 17.3 & \\
\hline \multirow{3}{*}{$\begin{array}{l}\text { Inadequate info about } \\
\text { Islamic banking } \\
\text { services }\end{array}$} & Disagree & 6 & 12.7 & -6.7 & \multirow{3}{*}{$\begin{array}{l}36.211 \\
.000^{*}\end{array}$} \\
\hline & Not sure & 2 & 12.7 & -10.7 & \\
\hline & Agree & 30 & 12.7 & 17.3 & \\
\hline \multirow{3}{*}{$\begin{array}{l}\text { Shortage of } \\
\text { experienced and } \\
\text { qualified staff }\end{array}$} & Disagree & 15 & 12.7 & 2.3 & \multirow{3}{*}{$\begin{array}{c}5.421 \\
.067\end{array}$} \\
\hline & Not sure & 6 & 12.7 & -6.7 & \\
\hline & Agree & 17 & 12.7 & 4.3 & \\
\hline \multirow{3}{*}{$\begin{array}{l}\text { Non availability of } \\
\text { good quality customer } \\
\text { services }\end{array}$} & Disagree & 21 & 12.7 & 8.3 & \multirow{3}{*}{$\begin{array}{l}13.000 \\
.002 *\end{array}$} \\
\hline & Not sure & 3 & 12.7 & -9.7 & \\
\hline & Agree & 14 & 12.7 & 1.3 & \\
\hline \multirow{3}{*}{$\begin{array}{l}\text { Low effectiveness of } \\
\text { services }\end{array}$} & Disagree & 18 & 12.7 & 5.3 & \multirow{3}{*}{$\begin{array}{c}4.000 \\
.135\end{array}$} \\
\hline & Not sure & 8 & 12.7 & -4.7 & \\
\hline & Agree & 12 & 12.7 & -.7 & \\
\hline \multirow{3}{*}{$\begin{array}{l}\text { High cost of banking } \\
\text { products and services }\end{array}$} & Disagree & 17 & 12.7 & 4.3 & \multirow{3}{*}{$\begin{array}{l}2.579 \\
.275\end{array}$} \\
\hline & Not sure & 12 & 12.7 & -.7 & \\
\hline & Agree & 9 & 12.7 & -3.7 & \\
\hline \multirow{3}{*}{$\begin{array}{l}\text { Small network of } \\
\text { branches }\end{array}$} & Disagree & 8 & 12.7 & -4.7 & \multirow{3}{*}{$\begin{array}{l}25.316 \\
.000^{*}\end{array}$} \\
\hline & Not sure & 3 & 12.7 & -9.7 & \\
\hline & Agree & 27 & 12.7 & 14.3 & \\
\hline \multirow{3}{*}{ Location of banks } & Disagree & 12 & 12.7 & -.7 & \multirow{3}{*}{$\begin{array}{c}15.842 \\
.000 *\end{array}$} \\
\hline & Not sure & 3 & 12.7 & -9.7 & \\
\hline & Agree & 23 & 12.7 & 10.3 & \\
\hline
\end{tabular}

* significant at .05 level of significance

With respect to low effectiveness of services, IBE and CBE as whole do not see it as a problem for expansion of IB. The result of IBE subsample is in aligns with that of overall sample. Moreover, p-value of .002 is not significant for CBE due to proportional difference between agree and disagree but due to huge difference from neutral group.

Both types of bank employees show that high cost of banking products and services is not a 


\section{Macrothink

barrier for IBS. In the last two factors, small network of branches and location of branches are significant barriers for promotion of IB. Both types of employees are showing their consensus on these factors. These results are significant at 0.05 level.

Thus according to IB employees subsample following are hindrances to IB growth

1) Ignorance To Teachings of Islam

2) Inadequate info about Islamic banking services

3) Trust deficiency towards Interest free banking

4) Small network of branches

5) Location of banks 
Table 4. Test Result of Conventional Banking

\begin{tabular}{|c|c|c|c|c|c|}
\hline Factors & & $\begin{array}{l}\text { Observed } \\
\mathrm{N}\end{array}$ & $\begin{array}{l}\text { Expected } \\
\mathrm{N}\end{array}$ & Residual & $\begin{array}{l}\text { Chi Square } \\
\text { Test Value } \\
\text { with } \\
\text { Significance }\end{array}$ \\
\hline \multirow{3}{*}{$\begin{array}{l}\text { Ignorance To financial } \\
\text { Teachings of Islam }\end{array}$} & Disagree & 30 & 29.3 & .7 & \multirow{3}{*}{$\begin{array}{l}19.727 \\
.000^{*}\end{array}$} \\
\hline & Not sure & 12 & 29.3 & -17.3 & \\
\hline & Agree & 46 & 29.3 & 16.7 & \\
\hline \multirow{3}{*}{$\begin{array}{l}\text { Trust deficiency towards } \\
\text { Interest free banking }\end{array}$} & Disagree & 25 & 29.3 & -4.3 & \multirow{3}{*}{$\begin{array}{l}17.341 \\
.000^{*}\end{array}$} \\
\hline & Not sure & 16 & 29.3 & -13.3 & \\
\hline & Agree & 47 & 29.3 & 17.7 & \\
\hline \multirow{3}{*}{$\begin{array}{l}\text { Inadequate info about } \\
\text { Islamic banking services }\end{array}$} & Disagree & 21 & 29.3 & -8.3 & \multirow{3}{*}{$\begin{array}{l}32.205 \\
.000 *\end{array}$} \\
\hline & Not sure & 13 & 29.3 & -16.3 & \\
\hline & Agree & 54 & 29.3 & 24.7 & \\
\hline \multirow{3}{*}{$\begin{array}{l}\text { Shortage of experienced } \\
\text { and qualified staff }\end{array}$} & Disagree & 29 & 29.3 & -.3 & \multirow{3}{*}{$\begin{array}{l}28.659 \\
.000^{*}\end{array}$} \\
\hline & Not sure & 9 & 29.3 & -20.3 & \\
\hline & Agree & 50 & 29.3 & 20.7 & \\
\hline \multirow{3}{*}{$\begin{array}{l}\text { Non availability of good } \\
\text { quality customer services }\end{array}$} & Disagree & 40 & 29.3 & 10.7 & \multirow{3}{*}{$\begin{array}{l}14.068 \\
.001^{*}\end{array}$} \\
\hline & Not sure & 13 & 29.3 & -16.3 & \\
\hline & Agree & 35 & 29.3 & 5.7 & \\
\hline \multirow{3}{*}{$\begin{array}{l}\text { Low effectiveness of } \\
\text { services }\end{array}$} & Disagree & 36 & 29.3 & 6.7 & \multirow{3}{*}{$\begin{array}{l}7.795 \\
.002 *\end{array}$} \\
\hline & Not sure & 17 & 29.3 & -12.3 & \\
\hline & Agree & 35 & 29.3 & 5.7 & \\
\hline \multirow{3}{*}{$\begin{array}{l}\text { High cost of banking } \\
\text { products and services }\end{array}$} & Disagree & 30 & 29.3 & .7 & \multirow{3}{*}{$\begin{array}{l}4.386 \\
.112\end{array}$} \\
\hline & Not sure & 21 & 29.3 & -8.3 & \\
\hline & Agree & 37 & 29.3 & 7.7 & \\
\hline \multirow{3}{*}{$\begin{array}{l}\text { Small network of } \\
\text { branches }\end{array}$} & Disagree & 13 & 29.3 & -16.3 & \multirow{3}{*}{$\begin{array}{l}61.523 \\
.000 *\end{array}$} \\
\hline & Not sure & 11 & 29.3 & -18.3 & \\
\hline & Agree & 64 & 29.3 & 34.7 & \\
\hline \multirow{3}{*}{$\begin{array}{l}\text { Location of banks } \\
5\end{array}$} & Disagree & 26 & 29.3 & -3.3 & \multirow{3}{*}{$\begin{array}{l}7.386 \\
.025 *\end{array}$} \\
\hline & Not sure & 21 & 29.3 & -8.3 & \\
\hline & Agree & 41 & 29.3 & 11.7 & \\
\hline
\end{tabular}

* significant at .05 level of significance

While CB employees consider following to major hurdle to IB growth

1) Small network of branches

2) Inadequate info about Islamic banking services 
3) Trust deficiency towards Interest free banking

4) Ignorance To financial Teachings of Islam

5) Location of banks

\section{Conclusion}

There has been a tremendous growth in IB all over the entire world especially in Muslim countries. Pakistan is the second largest Islamic country in the world in terms of population, boasting over 98\% Muslim population. Although concept of IB in Pakistan traces its roots back to late 70 s, still share of IB is modest i.e. $6.4 \%$. It still remains a surprise why has Islamic banking not touched the heights as expected? The researcher has tried to debate on this issue as a banker. According to this study there are number of factors contributing in the slow progress of IB i.e. small network of branches, inadequate info about Islamic banking services, ignorance to financial Teachings of Islam, trust deficiency towards Interest free banking, location of banks and shortage of experienced and qualified staff. The findings of this study reveal that people have serious reservations about the truly Islamic nature of IB and they don't consider current IB according to the true teachings of Islam. SBP being the regulator of all financial activities in Pakistan needs to revaluate its regulatory and supervisory role. Although SBP have taken several steps including establishment of its Shariah Board for compliance to sharia laws. However, lot of work needs to be done in this regard. The results of this research also identify the need of more work for existing Islamic banks to make their products acceptable for common man. While each Islamic Bank has appointed Shariah Advisor, responsible for Shariah compliance matters. But its role needs to be looked at. Marketing strategies of Islamic Banks may be partially held responsible for low market share. Existing marketing approaches need to revamp and Islamic banks need to come up with new marketing ideas to attract more customers. Islamic Banks should try to reach more people by opening more branches and it will certainly increase public confidence on them. Islamic banks need to expedite their expansion plans. In addition to this banks need to train their existing staff to deal with IB products. Workshops, training sessions and seminars are good way to overcome the lack of qualified personnel. The results of this study provide some useful insight into the hurdles faced by IB industry and it will pave the way for further research in this area involving different stakeholders' opinion and their demographic variables.

\section{References}

Abduh, Muhamad and Omar, Mohd. Azmi. (2010). Who patronizes Islamic banks in Indonesia, Australian Journal of Islamic Law, Management and Finance, Vol. 1 No. 1, pp.48-63.

Abdullah, N. I., Dusuki, A. W. (2007). Why do Malaysian customers patronise Islamic banks?

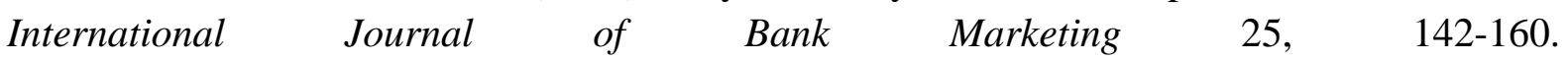
http://dx.doi.org/10.1108/02652320710739850

Al-Ajmi, J., Hussain, H. A., and Al-Saleh, N. (2009). Clients of conventional and Islamic banks in Bahrain How they choose which bank to patronize. International Journal of Social 
Economics 36, 1086-1112. http://dx.doi.org/10.1108/03068290910992642

Awan, A. G. (2009). COMPARISON OF ISLAMIC AND CONVENTIONAL BANKING IN PAKISTAN, paper presented at 2nd CBRC, 14 November, Lahore, Pakistan, available at: http://www.ciitlahore.edu.pk/pl/abrc/Proceedings/proceedings.htm (20 November 2010).

Erol, C., El-Bdour, R. (1989). Attitude, behaviour and patronage factors of bank customers towards Islamic banks. International Journal of Bank Marketing 7, 31-37. http://dx.doi.org/10.1108/02652328910132060

Gerrard, P., Cunningham, J.B., (1997). Islamic banking: a study in Singapore. International Journal of Bank Marketing 15, 204-16. http://dx.doi.org/10.1108/02652329710184433

Haque, A., Osman, J., and Ismail, A.Z.H. (2009). Factor Influences Selection of Islamic Banking: A Study on Malaysian Customer Preferences. American Journal of Applied Sciences 6, 922-928. http://dx.doi.org/10.3844/ajassp.2009.922.928

Hegazy, I. (1995). An empirical comparative study between Islamic and commercial banks' selection criteria in Egypt. International Journal of Commerce \& Management 5, 46-61

Khattak, N.A., Ur-Rehman, K. (2010). Customer satisfaction and awareness of Islamic banking system in Pakistan, African Journal of Business and Management 4, 662 - 671.

Mansour, W., Abdelhamid, M.B., Masood, O., and Niazi, G.S.K. (2010). Islamic banking and customers' preferences: the case of the UK. Qualitative Research in Financial Markets 2, 185-199. http://dx.doi.org/10.1108/17554171011091746

Moin, M.S. (2008). Performance of Islamic Banking and Conventional Banking in Pakistan: A Comparative Study available at: www.diva-portal.org/smash/get/diva2:113713/FULLTEXT01 (12 November 2010).

Naser, K., Jamal, A., Al-Khatib, L. (1999). Islamic banking: a study of customer satisfaction and preferences in Jordan. International Journal of Bank Marketing 17, 135-50. http://dx.doi.org/10.1108/02652329910269275

Quagraine, T. L. (2010). Employee Involvement As An Effective Management Tool in Decision-Making: A Case Study Of Merchant Bank (Ghana) Limited. available at: http://dspace.knust.edu.gh:8080/jspui/bitstream/123456789/877/1/TheodosiaLamleyQuagrain e.pdf (09 November 2010)

Rammal, H., Zurbrugg, R. (2007). Awareness of Islamic banking products among Muslims: the case of Australia. Journal of Financial Services Marketing 12, 65-74. http://dx.doi.org/10.1057/palgrave.fsm.4760060

Rashid, M., Hassan, M. K. (2009). Customer demographics affecting bank selection criteria, preference and market segmentation: Study on domestic Islamic banks in Bangladesh. International Journal of Business and Management 4, 131-146.

Sikand, Y. (1997). Trends in Islamic Banking and Finance. Islamic Voice.11-09, available at: http://www.islamicvoice.com/september.97/isla.htm (10 December 2010). 
Sudin, H., Norafifah, A., and Planisek, L. (1994). bank patronage factors of muslim and non muslim customers. Int. J. Bank Mark 12, 32-40. http://dx.doi.org/10.1108/02652329410049599

Wardey, I. (2010). Islamic Finance in the Global Economy, Edinburgh University Press. Edinburgh, http://www.sbp.org.pk/publications/schedule_banks/index.htm (10 October 2010) 